\title{
[4]
}

\section{Research on and Life with Servants}

Colonial anthropologists did not, as James Murray noted, study masters and servants. Because of tensions, there was little social interaction between anthropologists and white settlers and officials. Beyond highly ritualized encounters in colonial households by which the formalities of "calling" etiquette and the standards of white civilized society were observed, anthropologists may have had little opportunity to see how relationships between servants and employers were structured in everyday interaction. But this is not a sufficient explanation of why this particular occupational domain was left unexplored. And unexplored it was, for nowhere is it to be found in the established annals of Zambian labor history, colonial and present, even though, like most other whites, colonial investigators of anthropology and history kept servants. These workers seem, however, to have disappeared from social consciousness into oblivion.

Thus domestic service has been and, with a few exceptions, still is taken for granted, receiving a "no questions asked" approach from social scientists. Yet in postcolonial Zambia as in much of the rest of the world, servants are still with us. Part of the challenge of my research as it developed over the years has been to retrieve a sense of history-a changing one-of domestic service from among scattered archival records and between the lines of texts concerned with other issues. I also tried to establish a profile of domestic-service practices in postcolonial Zambia in the mid-1980s in order to explore the extent to which old habits had persisted. Finally, I sought to come to grips with what it meant to be a servant and an employer in the late colonial situation, and how these two places are experienced by the individuals who hold them today.

As a discussion of the methods of my research this chapter functions as a 
bridge between the colonial and the postcolonial periods in my examination of domestic service. I first reflect on the data-collecting procedures I used to give Part I its historical dimension. To provide a backdrop for Part III, I discuss my anthropological field research and attempts at participant observation, and comment on the intersubjective experience of the research process which has influenced my presentation and interpretation.

\section{Making Servants Visible}

Between 1981 and 1983 I sought to retrieve evidence about servants and their employers from the published literature on Northern Rhodesia and Zambia available in library collections in the United States, in particular, the Africana Collection at Northwestern University, my academic home since 1982. Simultaneously, I read whatever I could find of studies on domestic service in other places and other times in order to gain a comparative understanding of the processes that had shaped and changed this occupation over time in relation to demographic and economic shifts and different cultural and ideological influences. I spent the summer of 1982 in England, culling the official depository of colonial records from Northern Rhodesia at the Public Records Office in London in order to establish some sense of a historical trajectory of the legal measures and rules that had structured the place of servants in relation to employers and other workers over time.

This research provided a record of occupational roles rather than a sense of individuals with personal concerns of their own. In an attempt to infuse the record with that sense of personhood, I contacted people who had been employers of servants in Northern Rhodesia. Several British colleagues with research experience in southern Africa helped with advice and suggestions of contacts. In particular, J. C. Mitchell and Arnold Epstein, two of the prominent anthropologists associated with the urban research conducted at the Rhodes-Livingstone Institute during the 1950s, kindly tapped their memories about domestic-service practices at that time and made available special records for my use. I also placed an advertisement in the classified columns of the London Times in August 1982; "For a study of domestic servants in Lusaka, Zambia, during the colonial period and at present, I would appreciate hearing from anyone who has reminiscences, recollections or anecdotes. Of particular interest is information on terms of employment, level of wages and how it was calculated, accommodation, preference for servants from certain ethnic groups, and explanations of why so few women were employed as domestic servants. I am also interested in photographs of servants at work or at leisure." In March 1983 another advertisement went into the Overseas Pensioner, the newsletter of the Overseas Service Pensioners' Association in England. And in October 
1983, a note about my study was featured in News from Zambia, a newsletter compiled from the Zambian press at the London office of Zambia Consolidated Copper Mines, one of the parastatal companies, whose editor, Dick Hobson, provided me with much information and many contacts. Its mailing list includes many members of the Zambia Society, an association comprised largely of former colonial officials interested in keeping up connections and sharing concerns and news about a country in which many of them lived for good parts of their lives. Among them, these notices yielded nine written responses, which prompted exchanges of questions and information. Some of the individuals who responded continued to offer their insights for the duration of my entire study, and their advice produced additional contacts over subsequent years.

Gradually I began to establish a profile of domestic service during the colonial period. There were still many gaps, and as yet I had little substantive information about the postcolonial situation. At that point, I proposed research in Zambia and applied for funding to investigate the dynamics of domestic employment on several levels: first, the changing structure of the labor force in domestic service, over time and in relation to national employment patterns; second, the changing content of the employer-employee relationship with special attention to the differences in work conditions of men and women; and third, the changing relationships among domestic workers and between them and other workers.

Having secured the necessary funding, I arrived in Lusaka at the beginning of October 1983. I spent nine months in Zambia during that field trip and returned for three months during the summer of 1985 to tie up ioose ends and to pursue certain issues in more detail. Traveling between the United States and Zambia during those years, I made stops in England for additional archival work, including the collections at Rhodes House, and visited some of the people with whom I had corresponded. During summer 1986, I made several such calls in an effort to try to understand in particular what it was like to be a white employer of black servants during the political upheaval and rapidly changing times of the last decade of colonial rule. Because my attempts in Zambia to engage whites who had remained after the coming of independence in detailed discussion had been largely fruitless, in fall 1986, I sent some fifteen letters to people in Great Britain whose name had been given me by close contacts. Ten of them responded to my inquiries and helped me clarify the answers to a number of questions.

\section{Research on Domestic Service}

My research in Zambia led to the need for more archival work, the collection of employment and economic statistics, a survey of actual em- 
ployment practices, biographical work, and some kind of participant observation. These various components of the research at times overlapped, but for the purpose of this discussion I present them as more discrete than in fact they were.

\section{A Survey of Servants and Employers}

Servants in Zambia today continue to be taken for granted. Everybody supposedly knows what having servants is like, what to expect and not to expect of them, and shares these insights with newcomers. But beyond anecdotes, little substantive information exists about servants and their employers in postcolonial Zambia. Domestic service has not been enumerated as a distinct employment category by the Central Statistical Office since 1968. Although the Zambia National Provident Fund (ZNPF) has operated a registration scheme of urban servants for pension purposes since 1973, not all employers register their servants. The ZNPF's figures for servants were not categorized by sex, and proved to be of little help as an indicator of the numerical size and composition of the occupation. To get at these and other factors, I had to construct a sample survey that would fairly encompass the kind of variations of domestic service practiced in Lusaka today. I wanted to explore whether or not, and if so, how, such factors as an employer's ethnic or national background, occupation, and the length of time of residence in Zambia or of keeping servants influenced employment practices. I also wanted to know whether or not a servant's ethnic background, education, employment experience, age, and sex shaped discernible differences in his or her experience in domestic service. And I wished to learn about about the kinds of lives servants and their employers lived beyond their interaction in the household setting.

The available statistics on Lusaka's population contained no information on the ethnic/national and occupational composition of residential areas. To construct a sample that would control for these factors, I drew on my own understanding of Lusaka's population composition and sought advice from local colleagues. I thus planned my sample as a survey of every tenth house in two of Lusaka's low-density areas, Woodlands and Kabulonga, which would allow an inclusion of servant-keeping householders who worked in government as well as in private business and who represented Zambians and several foreign nationalities. As the survey got under way, I quickly realized that the resident Asians and the Eurafrican population were being left out. To remedy this, I selected two areas that during the colonial period were designated specifically for them: an area with a heavy concentration of Asian traders and the former Eurafrican part of town. Appproximately every tenth house was surveyed there as well. This is to say that the sample survey was readjusted as it was undertaken to control 
for those factors I was concerned to learn about. What at the outset I had hoped would become a random sample survey thus turned out to be in the nature of a quota sample.

I composed two questionnaires to use in the survey, one for the servant and one for his or her employer, which I had begun to work on before I arrived in Zambia. I had made a list of the of issues I wanted to explore and had given much thought to how and what kinds of questions to ask. When I arrived in Lusaka in October 1983, I discussed these issues with local colleagues, received their advice on what else to include in the survey and how to approach asking questions. I drafted a preliminary set of the two questionnaires, which I showed to my colleagues and pretested with the help of my chief assistant. Then I drafted the format of the questionnaires used in the actual survey.

To administer a survey of this kind required several participants. My chief assistant, Susan Antkiewicz, the wife of a North American history colleague at the University of Zambia, had been involved in a variety of research work in Lusaka and already in 1981 had indicated her interest in participating in my future research on domestic service. She and I each headed a team, the counterpart of which was a Zambian assistant. On the recommendations of colleagues, I engaged three Zambian students from the university for this work: Lameck Mwaba, who had just completed a B.A. in public administration and was unemployed; Stella Moyo, who held a B.A. in economics and was taking postgraduate courses in international law; and Ethel Chongo, who was studying for her B.A. in African development studies. We all met several times before beginning the actual survey, and I explained to them my interest in the domestic service occupation. They were puzzled at first, since they assumed-judging perhaps from syndicated American programs shown on local television - that everyone where I came from kept servants. They tested the questionnaire themselves, and in the end we eliminated a couple of questions that appeared intractable. Then we set out.

The survey required mobility. In my previous work in Lusaka I had used, first, a small motorcycle, then a bicycle, and finally public transportation in the form of the minibus to get to the compound. Clearly, this would not do. I was fortunate to be able to hire a Landrover and driver from the Institute of African Studies of the University of Zambia, where I was a research affiliate. The driver picked us up each workday at 1 P.M., dropped us in the residential areas at a spot I specified in advance, and collected us again at a specified place at 6 P.M. This was the time period during which, I thought, we would be most unlikely to upset servants' work in the household. The majority of the heavy tasks are done in the morning, and in some households servants have some time off after lunch, which in this part of former British Africa is between 1 and 2 P.M. We chose to continue till six 


\section{Encountering Domestic Service}

in the hope of reaching employers who worked away from home when they returned at five.

I had targeted the residential areas into subsets of house blocks, using aerial photographs and surveyers' plot maps. When the driver left us, Susan and her assistant would approach one subset and I and my assistant another. If no one was home at the house, or if the householder declined to be interviewed, we would go on to the next house. We would approach the gate, alert the guard or servant to the presence of visitors and ask him to inform the madam. If there was no gate, we walked directly to the front door. We would inform the householder about the nature of the survey and invite him or her to participate. If the invitation was accepted, we white women would accompany the householder, while our Zambian assistants interviewed the chief servant of the household. I insisted on conducting these interviews separately and encouraged the assistants to interview the servant in the servant quarters in order to get a glimpse of what the living conditions were like.

Studies of domestic service which involved interviews undertaken in South Africa and what then was Southern Rhodesia had led me to anticipate that my research team might encounter hostility from householders when we asked them questions about their servants, ${ }^{1}$ but in fact we met very little. I attribute this to the more relaxed racial atmosphere in Zambia as compared with the countries in the south and to our approach: a white woman accompanied by a young Zambian perhaps did not give rise to the kind of suspicion that an all-Zambian research team might have in a city where everyone fears thieves and burglars. To be sure, some householders made excuses. But others who were busy invited us to return the next day. Without exception, the Zambian householders were the most approachable, which I attribute to traditional patterns of hospitality: we were often invited inside the house and seated before we had even got a chance to explain the reason for our coming. (There were amusing moments as a result, such as the time we already had been seated on the living room couch when the male Zambian householder told us he had just sacked his servant the day before- - but wouldn't we like to talk to him about something else?) The hostility we did meet came from one clearly identifiable source: whites who had stayed put since the colonial period. From them we got more excuses-and closer to having the door slammed in our facesthan from anyone else.

One of the residential areas I had initially targeted for our work included a housing enclave for high-level government officials but once under way, I

1. Jacklyn Cock, Maids and Madams: A Study in the Politics of Exploitation (Johannesburg: Ravan Press, 1980), pp. 19-20, and A. K. H. Weinrich, Mucheke: Race, Status, and Politics in a Rhodesian Community (New York: Holmes and Meier, 1976), pp. 215-217. 
decided we should not interview there, in order not to give the impression that we wanted to pry into the private affairs of public officials. For the same reason we also avoided the residences of ambassadors and consuls. We did, however, include lower level embassy personnel in the survey. Sometimes the pragmatics of pedestrian field research made such avoidance rules hard to observe. I recall one very hot afternoon when Ethel and I had been walking from door to door for what seemed like an eternity. Up came an ambassadors residence, and I said: "let's give it a try." The guard announced our presence, a servant was sent to collect us, and soon we were seated in a reception room and brought cold drinks. The ambassador's wife appeared and listened to our story. She was sorry, she said, but protocol prevented her from revealing household details. Yet she went on talking and talking. The embassy circles were a bit nervous then, for a long-time, trusted servant in the British High Commission had been involved in a check-forging scheme. This I knew, for it had been reported in the newspaper. ${ }^{2}$ The rest of what she revealed remains confidential.

When we were allowed to interview, each member of the team went through his or her separate questionnaire. Susan and I rotated the Zambian assistants between us in order not to develop a procedural routine that became so fixed that it made us ignore the specifics of the given household. I did work more with Lameck, though. He and I would team up on several Saturdays, descending on private householders who otherwise worked away from home in the early morning. This had its embarrassing moments, for example, one Saturday morning when a male householder appeared in his dressing gown at the door. But he spoke Swedish, and I gave him a big Danish grin. We ended up having morning tea with him and his wife in their dressing gowns.

The questionnaires were designed to elicit information from both servant and employer about occupational background, the length and variety of their involvement with domestic service, the work regime, duties and responsibilities of both servant and employer, the composition of the households of the two parties, and leisure-time interaction and lifestyle of both. On the last issues we sought in particular to engage people in informal conversation, by conducting fairly structured small-talk on the completion of the formal questionnaire. If the assistants finished interviewing the servant before the interview with the employer was completed, they were instructed to come into the living room and seat themselves inconspicuously. On the other hand, we would extend our small talk if the assistants went on longer. All the assistants were multilingual and conducted their inteviews in Nyanja or one or other of the local languages. Susan and I interviewed most of the employers in English. Our linguistic

2. "Cook on Graft Charge," Zambia Daily Mail, October 17 (1983), p. 3. 
problems occurred mainly in Asian households where in some cases the women we interviewed knew very little English. Yet our language skills were so limited in comparison to those of our Zambian assistants. (One afternoon I interviewed employers in a Norwegian-speaking household; I spoke Danish, and they spoke Norwegian. I remember my thrill when Lamack came back in: at least he could hear that I could speak something in addition to English.) The interviews lasted anywhere from half an hour to more than an hour. They were conducted during the three hottest months of the year, and I was offered more soft drinks during the duration of this work than I have ever consumed before. We were also sometimes offered alcohol, which whether we really would have liked it or not, we always declined.

On days when all the three Zambian research assistants were available, Ethel went off on a special assignment: interviewing servants and some employers in "the flats," the apartment buildings that a number of private firms, government, and parastatal companies have constructed to accommodate junior-level employees. When I decided it was necessary to extend this work, her younger brother, Kizito, a high-school student, received onthe-job training and helped her.

How reliable is the information we collected in these interviews? Some items such as wages, hours of work, holiday arrangements, length of employement, and ZNPF registration can be cross-checked, for both servant and employer were questioned about these matters. We as interviewers developed a sense of whether or not the person was honest in answering or merely telling a story. Some people were difficult to interview and consistently had to be prompted, whereas others were extremely easy to talk to and rapport developed quickly. To get at the question of how employers really viewed their servants, we asked them what advice they would give a newcomer who had never kept servants. Answers to this question revealed that regardless of whatever else they told us, employers do not trust their servants. While they would rather not bother about them, they feel they have to because they never know what they are up to. Most of these interviews contain litanies of complaints from both servants and employers; we found few households with relaxed interpersonal relations.

The members of the interviewing teams were instructed to write up, on the evening of the interview, a narrative of it, the characteristics of its setting, their reception, and whatever they learned outside the framework of the questions. These narratives tell, among other things, of the amusements and disappointments of the work, such as long walks in the hot sunshine knocking on too many gates, pursuit by ferocious dogs, the location of the tallest fences with the highest spikes in Lusaka, and hostile madams, British or southern African, posing in front of the main door with legs astride, arms on hips, saying, as only they can, "Yiiis?"-meaning, I 
suppose, "Who do you think you are to come here?" They also tell of the lives of a cosmopolitan crowd, friendly receptions, interesting conversations, and of invitations to come again. But first and foremost, they relate the spectacular difference between the life and circumstances of servants and those of the persons they work for.

\section{Special Collections}

During the interview period, I also spent time with the special collection of Zambiana and government documents in the university library, reading travel descriptions, biographies and autobiographies, novels-anything in which I could find information about servants and their employers. When the survey was completed, I spent some months perusing files in the National Archives of Zambia in Lusaka, and several days in the National Archives of Zimbabwe, looking at early records from the period when the two Rhodesias were administered from South Africa. In addition there were newspapers, magazines, and newsletters published during the colonial period, reports of colonial commissions, and law reports. Perhaps the driest of this reading, the reports of the Legislative Council, in fact gave me a better sense of the tensions among the colonial whites than any of the other documents. With it all, I was beginning to fill in the gaps in the record I had established before my arrival in Zambia.

My reading also raised new questions. Scattered remarks in labor reports, about servants' attempts to form unions in the postwar years, for example, made me eager for more information. I spoke to union officials of the Zambia Congress of Trade Unions at the Kitwe headquarters. While they found my observations interesting, they knew nothing about these attempts and could add little to what I already knew. But like everyone I spoke to during this research, they had their stories and anecdotes about servants and employers. And they were willing to talk about the prospects - which they considered to be negligible - for unionization among servants today. I also met mining officials and the mine archivist of Zambia Consolidated Copper Mines in Kitwe with the faint (but unfulfilled) hope that the records on miners' attempts to form a union in the late 1940s would contain information also about servants' union activities. I spent about a month in the ZNPF registration office for domestic servants in Lusaka going through records and discussing the servants' situation with its staff, as well as with the officials at the ZNPF headquarters. I spoke with statisticians in the Central Statistical Office about the problems of sampling domestic servants. I consulted officers at the labor exchange and looked at registration data, while Lameck interviewed some of the men lined up outside the office who hoped to find jobs as servants. Lameck inteviewed officers at the police station in one of the residential areas we had sampled 
in order to get information about the types of cases employers and servants bring in. And Lameck and I interviewed personnel managers in a number of private firms and parastatal companies to learn about their policies in regard to paying for servants for certain ranks of employees.

\section{Servants Everywhere}

At this point in my work, servants had become anything but invisible. What I read about them in the records obviously still left them distant. But the reading was done against the backdrop of an urban setting, where every unemployed man is a potential servant. So I encountered them everywhere. During my cigarette breaks as I sat on the low wall surrounding the National Archives, men passing by would often approach me asking for work, telling me of their skills in domestic arts, whether or not they really had them, such as boiling eggs or peeling potatoes. Men, and sometimes women, would also call at the house where I happened to stay. This did not occur every day, but it happened often enough to dramatize the wretched employment situation in Lusaka. Some of these people would be men who had seen me when I visited my friends in the compound. From the point of view of the unemployed person, every white woman is a potential employer.

\section{Living with Servants}

In order to obtain the cooperation of both servants and their employers, I had to confront the question of how to gain access beyond the setting of formal interviews. Domestic service, perhaps because of its location within the private household, seems to invite nonconventional approaches for purposes of close-range research. ${ }^{3}$ I considered two options: establishing my own servant-keeping household, using myself as a guinea pig to register the details of everyday interaction, or to move into already established households with persons who employed servants. I quickly negated the first option. Even if housing had been available in Lusaka's crowded housing market, I did not wish to live as a single housekeeper-in part because a household that was empty most of day was vulnerable to break-ins and thefts, in part because I anticipated that I would be an unsuccessful madam. Given my dislike of the domestic service institution, I would have paid what local residents term exorbitant wages, leave the organization of

3. See Evelyn Nakano Glenn, Issei, Nissei, War Bride: Three Generations of Japanese American Women in Domestic Service (Philadelphia: Temple University Press, 1986), pp. xxvi, and Judith Rollins, Between Women: Domestics and Their Employers (Philadelphia: Temple University Press, 1985), pp. 8-11. 
household tasks and their timing to the servant, and have trouble making authoritarian decisions about how, where, and when the servant's presence was required. I would have been too uncertain, too talkative, and too lacking the firmness that household manuals suggest madams exhibit. Keeping my own servant would have taught me nothing about other people's servant-keeping practices.

I chose the second option. From my experience of living as a paying guest in a private household while doing research in Lusaka in 1981, I knew that it would give me a strategic position from which both to observe and participate in the interactions around the daily routine of household activity. My plan was to stay in several households of varied national and occupational backgrounds which had engaged domestic servants for varying lengths of time. But in most servant-employing Zambian households there are pressures on space and resources with relatives living in and visitors coming and going, so I soon gave up the idea of staying in one. My desire to make a live-in arrangement with a household of British or southern African background who had remained in Zambia after independence was also soon quashed. Although I had introductions from former Northern Rhodesians in Britain and from long-time expatriates in Zambia and had discussed the matter at length with local whites who had many contacts with the kinds of households I was interested in, none of them wanted my presence. When meeting some of the old-timers, I was initially received with an overbearing curiosity that, when I persisted with my questions, turned into suspicion and in some cases outright hostility. "What's this study for, anyway?" was the response of one of these white madams when I inquired about contacts we both knew she had and which I knew would be helpful. Her assumption, in my interpretation of her remarks, is that since they live with them, matters about servants are supposed to be well known already, so what is there to know? The white women we interviewed in the survey who were old-timers were far from expansive in their comments. We had the impression they did not want to talk about their servants, at least not discursively.

The Englishwoman's home may well be her castle and her desire for privacy pronounced, yet there was something else at stake. I first blamed myself for their negative response. I do ask many questions and perhaps in a more straightforward manner than is considered polite by persons concerned with standards and etiquette. But so do many other people in Zambia today without being considered rude. Being a single woman might also have been a liability, a disturbing element in the private household. Yet, many householders in Lusaka accommodate nonmembers for varying lengths of time because of the acute housing shortage. Their reactions disturbed me. I finally concluded that their hostility, though directed toward me, arose because of the troublesome nature of my research topic. It 


\section{Encountering Domestic Service}

is far easier to speak about servants as an investigator than to live with them as a householder. I had approached my research from a distance; I had not experienced the vexations that were part of the daily enactment of domestic service and the difficulties employers experience in their relationship with servants. Servants aren't what they used to be, such employers say, and there are more problems today in keeping them in their place and making them work satisfactorily. Servants and their problems are issues many of the old-time employers would rather not be reminded of, let alone be forced to explore by a probing researcher.

During 1983 and 1984 and again on my return in 1985, I lived for varying lengths of time in four households whose members were employed at the University of Zambia and had outlooks closer to my own. Two were from the United States, one from India, and one a Canadian-American household. With the exception of the last, they had all lived in other parts of Africa before coming to Zambia. The members of the Canadian-American household had previously lived in Zambia for some time. The servants were informed of my presence and told about my work. I paid a monthly fee for room and board and I asked my hosts to remunerate their servants out of it for the additional work my presence caused. I in turn tipped the servants when they had done special tasks for me and, following the practice of my hosts, brought presents to some of them on my return in 1985.

Although these households are not representative of the range of persons who employ servants, they exposed me to several variations of service arrangements and made me sensitive to both the joys and the problems of servant-employer relationships. Freed from housework, laundry, and cleaning, I had more time than I have ever had before or since for my own research activities. For out-of-the-ordinary events I might prepare a special dish (much in the manner of the Western husband who enjoys weekend gourmet cooking, leaving the dirty work and the dishes for the wife). Living in these different households, I was exposed to a wider circle of people in leisure-time interaction than I would have been had I established my own household. When learning about the nature of my research, most of the people I met offered comments from their own experience. Their anecdotes about life with servants and hints about tropical household management could fill another book. My understanding of the social lives of people who keep servants is influenced by this more extensive but less formal interaction and draws as well on information I collected in the sample survey.

Members of my households had lived in Lusaka for varying lengths of time, and although there were university teachers in each household, they managed their relationships with servants very differently. Crudely typecasting them, the Canadian-American couple who had lived in Lusaka for the shortest time, were "liberals" who tried to put as few demands as 
possible on their middle-aged woman servant. She lived in a nearby compound, commuted on a bicycle given to her by previous expatriate employers, arrived after breakfast and returned to her home before sunset. The household routine was accommodated to her health problems, and the employers sometimes helped her with her own economic household problems. The relationship within the household was caring, but in a distant way because of language problems. Of the households I lived in, the interpersonal atmosphere in this one seemed to me the most artificial.

The American single head of household, who had been in Lusaka a bit longer than the Canadian-American couple, had previously lived in Malawi, Kenya, and Nigeria. Because her working day of teaching and meetings was filled with personal contact, she insisted on privacy at home. She did not want her manservant to bother her, and their relationship was marked by distance. Beyond his daily routine of cleaning, washing, and a bit of garden work, she preferred to consider him irrelevant. She did not want to know what went on in the servants' quarters where several people lived; it was none of her business, she said. Because of this apparent noninterference, I thought for a long time that the relationship in this household was relaxed.

Members of the second American household had lived in Lusaka for about seven years, and the husband had spent time in Tanzania as well. They had employed one servant before the man who worked for them now. Their relationship to the servant could be labeled one of despair. As a newly arrived expatriate woman, the wife had initially wanted to be involved. Her trust and good will, however, had been misused; in one instance, there was a burglary, planned by her previous servant. Now after several years of employing them, she insisted that she couldn't "handle" servants. She disliked the idea of having them, although her husband was more positively inclined. They kept up jovial relations with their servant when he worked inside the house but she wanted nothing to do with his private life. She was as skilled at interpreting the servant's reactions as he was of hers. The atmosphere in the servant-employer relationship in this household was one of uncertainty: "you never know what he is up to." In my judgment, the routine in this household functioned smoothly.

I stayed the longest with my Indian hosts, who had lived in Lusaka since the early 1970s and spent several years in Ghana before that. They employed a full-time man servant whose wife did half-time work in the kitchen and, on her husband's day off, in the house. The servants had two children below school age. The relationship of employers with servants in this household could be typed as paternalistic. The employers assumed several caretaking functions for their servants' household, related lovingly to the servants' oldest child, and wished with the best of intentions to advise the servants on how to handle family life and household economy. Yet in a 


\section{Encountering Domestic Service}

paternalistic relationship, one party is considered childlike. Although the employers were more well intentioned regarding their servants' welfare than any of the others with whom I lived, they experienced more trouble in the day-to-day running of household activity. More frustrations were expressed here, by the employers as well as by the servants, of the other not living up to expectations. The servants did not work properly, in the employers' view, and in the view of the servants, the employers did not help them enough. There were constant trials and tribulations in this household. As I experienced it, the atmosphere between servants and employers in this household was tense.

If these arrangements allowed me to enjoy the comforts of domestic service, they also confronted me with many of its problems. As a participating member of these households, it was impossible to keep up the anthropologist's stance as an objective observer. My observations were no longer those of academic distance but of daily encounters. I doubt that my presence to any large extent changed the manner in which these householders interacted with their servants, for they were reenacting practices that already had become routinized. There may have been fewer harsh words when I was around. But when I argued with my hosts or made suggestions about reforming practices, they would do things their way, not mine.

I tried not to argue with my hosts, hoping in that way to see household activity unfold as it perhaps would have done without my presence. But of course my presence did create a difference, for there was a new household member for the servant to contend with. Moreover, my position was ambiguous. I was not the person who brought in the bread, yet I seemed to have a lot of money. Sometimes I was out a lot, at other times I would spend a good deal of the daytime in the house. I had different visitors. Unlike most expatriates, I did not drive a car. I paid more attention to the servants than guests normally did. I engaged the servants in conversations and asked them questions. I tried to chat informally as I would do with persons in any household. My questions may at times have annoyed these servants, for who was I to snoop into their lives? They did talk to me without first being spoken to, however, and asked questions, about my assistants, what we were doing, and where I had been. They also asked for favors. And sometimes they appealed to me to raise particular issues with the employers. Yet my occasional role as intermediary between the two was limited. And although I was closer to the servants in terms of conversation, from their perspective my place was clear: I "belonged to" the employers and I had resources that were desirable.

In the second household described above, where the relationship with the servant was kept distant and noninterference was the order of the day, the servant stole what by Zambian standards was a large amount of cash and 
travelers' checks in foreign currency from the locked nightstand in my room. Even this servant who did not spend much time in the house knew every nook and cranny and what we kept there. This incident served to verify the employers' truism: a servant was not to be trusted. Only through this occurrence that directly involved me did I begin to understand, to know, some of the vexing meaning of life with servants in a city such as Lusaka.

It was through my intersubjective experience that I came to understand how distance between servants and their employers was systematically expressed and re-created in both space and social structure. I hope this extremely personalized experience in the field has enriched my analysis of contemporary servant-employer interaction without my losing sight of the class underpinnings of their relationship.

\section{Lives: Servants and Their Employers}

In order to qualify the generalizations I found expressed in the official records, I tried to capture the personal viewpoints and experiences of elderly servants and white former-employers who had lived through the last period of colonial rule. I did so by collecting biographies that focused on working lives from a number of individuals, in informal circumstances.

I met several persons, both servants and employers, who fitted these criteria when undertaking the sample survey. The occupational histories their life and work as servants or employers contained were complex and their observations interesting and informative. I could have called back on several of these households to engage the servant or the employer in longer-term discussion. I decided to not use this avenue because of the interference and intrusion into ongoing household activity such calls might impose on households I had selected as randomly as possible for sampling purposes. There was always in old-time white households that lingering curiosity of what I really was up to, and the suspicion, perhaps, of setting servants up for something. In some of these households in which servants spoke another Zambian language than Nyanja, which I know, I would have to bring along an assistant to interpret. This would add restrictive formality to an interviewing situation of, we hoped, free-flowing exchange, and perhaps make me more suspect in the view of white employers.

The life histories with focus on occupational experiences I did collect were obtained under more informal circumstances. I interviewed one lifetime servant in the neighborhood where I lived. His employers were friends of mine, and it was easier to gain rapport than through a stranger's household. The rest of the servants I spoke with, fifteen men and twelve women, lived in the compound where I had done my previous research in 


\section{Encountering Domestic Service}

Lusaka. My long-time assistant, who has lived there since its opening, identified these individuals for me. Several of them had now stopped work, some were still looking for jobs in domestic service, and some after a life of domestic toil had settled down to old-age poverty in urban retirement. Because of what I experienced as hostility from white old-time employers still living in Zambia, I interviewed former colonial employers who now live in England.

The information was obtained with difficulty and with much prompting on my part. Many of the servants I spoke to were not particularly articulate, perhaps as a result of their adjustment to a job in which they were expected always to be present without being seen and not talk unless they were spoken to. Most of them expressed surprise that anyone would be interested in such lives as theirs. Society devalues their work, and during the late colonial period servants who obediently and deferentially continued their work were considered to be politically suspect. Yet some of these old-time servants opened up, among them a couple of extremely good talkers who took pleasure in sharing their rich occupational histories with me. Some of them had enjoyed the perks of domestic service for whites and had in their own words led good and exciting lives that had taken them across the southern African continent. Others had experienced the domestic institution to be a particularly restricting one that had curtailed their own plans for living independent lives. Some had staged individual rebellions by quitting, yet many others stayed put. Most depressing to me, above all, was the sharp contrast between living conditions as these servants had known them and their life circumstances today: some of them had acquired nothing but a far-ranging and complex work history from their lifelong labor in domestic service.

I called on five households in England whose members had been longtime employers of domestic servants in Northern Rhodesia. Most of them had been members of the colonial administration and they had left the country at or soon after independence. They spanned two different cohorts of colonial employers: those who had come out in the days when the imperial order was taken for granted, that is, before the Great Depression, and those who had gone to Northern Rhodesia after World War II, when the colonial flags had begun to be taken down elsewhere. Generalizing from my limited data, it would not be incorrect to characterize the interwar generation as "paternal" in their relation to servants. The postwar group was more "liberal" in their attitude, yet also displayed a curious despair about servants who seemed to perform no longer according to old-time expectations.

Some of the members of these five households were among my original correspondents. That is to say that they are a somewhat biased sample. The persons who responded to my advertisements and who invited me into 
their homes had positive recollections of their life and work in Northern Rhodesia. People for whom life in the colony had been a troublesome experience did not respond to my call. My hosts were persons who were interested and concerned to exchange information about a country in which they had lived long and interesting periods of their lives and about individuals who often had been part of their lives for several years: their servants. They were also concerned to rectify the negative image of the colonizers to which they had been subjected in much of the scholarly literature of a previous generation.

My discussions with them did not take the form of structured interviews. They were extended informal conversations revolving around personal biography: reasons for coming to Northern Rhodesia, regional postings, marriage, the birth of children, rural versus urban locations, and social life and the nature of interaction among, between, and across the different racial groups. We discussed their changing experience of life with servants in relation to these settings and to the flow of events: the coming of the Federation, the rise of African political parties, and the general political mobilization before to independence.

In these conversations, I was particularly concerned to come to grips with the inherent paradox in such households as the colonial era was drawing to a close: the preparation in society at large of some Africans to take over the reins of the polity at independence, and the persistence within private households of a hierarchically structured labor process. These colonial employers did not find it necessary to revolutionize the domestic service institution from within. Postcolonial employers of servants, including Zambians, have not done so either. Gouldsbury's statement from the first decades of the century still pertains: "Servants, like the poor, are always with us, and nobody seems to care." 
